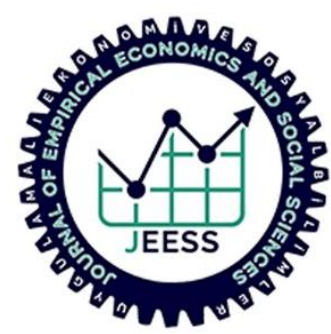

T. Köroğlu Doi: http://dx.doi.org/10.46959/jeess.606042

\title{
EVALUATING THE COST-BENEFIT OF A WASTE HEAT RECOVERY ENERGY SYSTEM WITH EXERGOECONOMICS
}

\section{Asst. Prof. Turgay KÖROĞLU*}

\begin{abstract}
While it is certain that life cannot exist without energy, it is impossible to think of the use and efficiency of energy systems outside economic conditions and constraints. For energy producers and consumers, the determination of the cost of unit energy or electricity is basically a result of the combined evaluation of the first law of thermodynamics and economy. However, the result of this approach is incapable of determining the source, location, and magnitude of the unutilized energy. From this point of view, the concept and analysis of the exergy resulting from the use of the first and second laws of thermodynamics is a method used both to fulfill the aforementioned deficiencies and to reveal the amount of exergy destroyed in any process. Moreover, the combination of exergy analysis with economic analysis, by pricing the exergy destruction, which is a result of the inefficiencies of the system and components examined, leads the investor in how much the inefficiencies in the system and components cost, and how this economic burden can be reduced. In summary, the cost of exergy destruction can be considered as a financial burden that needs to be reduced for more efficient and economic systems. The waste heat recovery method is used to reduce the amount of fuel, which the main system consumes, by recovering the excess energy released into the atmosphere via generating more energy. In this study, a waste heat energy system has been examined with exergy and exergoeconomical analyzes in order to obtain information that can improve both efficiency and economy, and the components that should be focused on and the contributions of these components to the whole system have been determined based on the results obtained. The study showed that exergoeconomic analysis is one of the methods that can be used to gain more information about systems for energy costing and economic optimization.
\end{abstract}

Keywords: Energy System, Waste Heat Recovery, Energy Economics, Exergy, Exergoeconomics.

Jel Classfications: $Q 4, N 7, O 1$.

* Bandırma Onyedi Eylül University, Maritime Faculty, Balıkesir, Turkey, e-mail: tkoroglu@ bandirma.edu.tr 


\section{ATIK ISI GERI KAZANIMI ENERJI SISTEMININ MALIYET FAYDASININ EKSERGOEKONOMİ İLE DEĞERLENDİRILMESI}

\section{ÖZET}

Enerji olmadan yaşamın olamayacağı kesin olmakla birlikte, enerji sistemlerinin kullanımını ve verimliliğini ekonomik durumlar ve kısıtlamalar dışında düşünmek imkansızdır. Enerji üreticileri ve tüketicileri için, birim enerji ya da elektrik maliyetinin belirlenmesi temelde ekonominin ve termodinamiğin birinci yasasının birlikte değerlendirilmesi neticesinde gerçekleşir. Ancak, bu yaklaşımın sonucu, kullanılamayan enerjinin kaynağını, yerini ve büyüklüğünü belirlemekte yetersizdir. Buradan hareketle, termodinamiğin birinci ve ikinci yasasının birlikte kullanılması neticesinde ortaya çıkmış olan ekserji kavramı ve analizi, hem bahsi geçen eksiklikleri tamamlamak hem de herhangi bir süreçte yıkıma uğramış ekserji miktarını ortaya çıkarmak için kullanılan bir yöntemdir. Ayrıca, incelenen sistem ve bileşenlerin verimsizliğinin bir sonucu olan ekserji tahribatının fiyatlandırllması yoluyla ekserji analizinin ekonomik analiz ile birleştirilmesi, sistem ve bileşenlerindeki verimsizliklerin maliyetinin ne kadar olduğu ve bu ekonomik yükün nasıl azaltılabileceği konusunda yatırımcıya yol gösterir. Özetle, ekserji yıkımının maliyeti, daha verimli ve ekonomik sistemler için azaltılması gereken mali bir yük olarak düşünülebilir. Atık ısı geri kazanım yöntemi, daha fazla enerji üreterek atmosfere salınan fazla enerjiyi geri kazanarak ana sistemin tükettiği yakıt miktarını azaltmak için kullanılır. Bu çalışmada, bir atık ısı enerji sistemi hem verimi hem de ekonomiyi daha iyi hale getirebilecek fikirler elde etmek adına ekserji ve eksergoekonomi analizleriyle incelenmiş, elde edilen sonuçlardan hareketle sistemi daha iyi hale getirmek için odaklanılması gereken bileşenler ve bu bileşenlerin bütün sisteme katkıları belirlenmiştir. Çalışma, eksergoekonomik analizin enerji maliyetlendirme ve ekonomik optimizasyon sistemleri hakkında daha fazla bilgi elde etmek için kullanılabilecek yöntemlerden biri olduğunu göstermiştir.

Anahtar Kelimeler: Enerji Sistemi, Atık Isl Geri Kazanımı, Enerji Ekonomisi, Ekserji, Eksergoekonomi.

Jel Sınıflandırması: $Q 4, N 7, O 1$.

\section{INTRODUCTION}

The rise of the fuel prices as well as of the concerns about the environmental pollution issues have forced to shift the energy required processes, hence energy systems, towards more efficient and less harmful designs. Therefore, from the engineering perspective, the energy efficiency, which could be defined as the ratio of the desired output to the required input for the production of the output (Cengel and Boles, 2015), is important to consume the resources responsibly and preserve the sustainability of the energy resources. On the other hand, efficiency is not adequate to examine the system on its own. It is required also to determine the cost of energy production and be economically beneficial with 
decreasing the costs if possible. Energy economics based on engineering economics is a well-established method to combines the energy analysis and the economic analysis to determine the cost of energy and cost of the system and its components (Bejan, Moran and Tsatsaronis, 1996). But the knowledge of how to decrease the costs is utterly gaining more and more importance.

As it is known, "energy can neither be destroyed nor created, it only changes forms"(Cengel and Boles, 2015). However, all energy forms are not equal in terms of quality, hence, exergy could be utilized to determine the distinction of the quality in terms of quantity. Exergy analysis is a method to reveal and evaluate the destruction of available energy, which is the wasted portion of the energy resources (Bejan et al., 1996), while a process occurs. It gives the direction of the improvement for a system to recover destructed exergy. This is related to economics in a simple way. The total cost of a system includes several costs such as investment, operation, and maintenance, fuel costs. What an economic analysis does not present is the cost of the inefficiencies within a system. Low efficient component or system will increase the cost of exergy destruction, which is unbeneficial. Exergoeconomics based on exergy and economic analyses is helpful to determine the costs, which can be prevented by increasing the efficiency or decreasing the exergy destruction and return as a profit to save investment or a benefit to reduce the cost of the final product (Bejan et al., 1996; Tsatsaronis, 1996). Moreover, more efficient systems will require less fuel in general, and fuel costs will also be reduced as well as the environmental impact of the system.

The efficiency of an energy system could be increased in several different ways. However, waste heat recovery (WHR) is a proven and available technology to harness excess energy, which is dissipated from the different heat sources of an energy system, mainly the exhaust due to having relatively high temperature and thus energy potential (T. Koroglu and Sogut, 2017). It has a potential to improve the system by 20\% (Mahmoudi, Fazli and Morad, 2018; Sprouse III and Depcik, 2013). Commonly, WHR systems are based on a thermodynamic cycle, called the "Rankine" cycle and the working fluid differs with respect to the temperature of the dissipated heat source as low, mid, and high range temperature and energy. Organic Rankine cycle (ORC) utilizes organic compounds as working fluid and is used mostly to capture low- and mid-grade energy (Mahmoudi et al., 2018; Song, Li, Gu and Zhang, 2014). Hence, it has been applied to internal combustion engines (ICE), which is the heart of vehicles and generators (Mahmoudi et al., 2018; Shi, Shu, Tian and Deng, 2018; Sprouse III and Depcik, 2013). Furthermore, the WHR systems also take place in the marine vessels as default and ORC systems are investigated for the attachment to the marine systems lately (Mondejar et al., 2018; Shu et al., 2013).

Schuster et al. investigated ORC with energy and economic analyses and resulted that it is better to use the cooling water of the main engine as a preheater (Schuster, Karellas, Kakaras, \& Spliethoff, 2009). Quoilin et al reviewed ORC systems with the technoeconomic approach (Quoilin, Van Den Broek, Declaye, Dewallef and Lemort, 2013). Fergani et al. evaluated the ORC system with exergy and exergoeconomic analyses and resulted that cyclohexane is the best fluid (Fergani, Touil and Morosuk, 
2016). Wang et al utilized economic analysis on a WHR ORC with 11 different fluids and optimized the system (Wang, $\mathrm{Li}, \mathrm{Li}$ and $\mathrm{Wu}, 2015$ ). He et al applied exergy analysis to select a working fluid for the ORC system attached to an LNG engine and resulted that five organic fluids could improve the fuel economy by more than $14 \%$ compared to that without ORC (He, Chang, Zhang, Shu, \& Duan, 2015). Song et al designed two ORC and applied energy, exergy, and economic analyses and results proved that efficiency rises and the system is economically feasible (Song, Song and Gu, 2015). Kalikatzarakis and Frangopoulos researched for an optimum thermoeconomic result of the ORC system with 21 different organic fluids, that is attached to the main engine of a ship (Kalikatzarakis and Frangopoulos, 2015). Shu et al investigated an ORC WHR system that is designed based on four weeks of data of a ship and applied thermal and economic analyses (Shu, Liu, Tian, Wang and Jing, 2017). Koroglu and Sogut applied exergy and exergoeconomic analyses to two conceptual WHR ORCs with different working fluids and resulted that saturated ORC is a better solution with R141b as working fluid in the light of the analyses (T. Koroglu and Sogut, 2017).

In this study, a simple ORC WHR system appended on the exhaust of MAN51/60DF (MAN Energy Solutions SE, 2019) dual-fueled (diesel and LNG) generators of an LNG carrier is investigated to reveal the efficiency and cost-profit improvement via exergy and exergoeconomic analyses. The main aim is to introduce the power of the exergy and exergoeconomic analyses to lead the designer/engineer for more efficient, environmentally friendly, and economically beneficial systems.

\section{METHOD}

Exergy is the available work potential of a system while it interacts with its environment (Cengel and Boles, 2015) as shown in Figure 1(Bejan et al., 1996; Koroglu, 2018). This approach shows the quality of the energy and each $j$ stream has its exergy with respect to the reference environment as (Bejan et al., 1996):

$$
\dot{E}_{J} \cong \dot{m}_{j}\left[\left(h_{j}-h_{0}\right)-T_{0}\left(s_{j}-s_{0}\right)\right]
$$

Figure 1: Definition of the Exergy [2], [20]

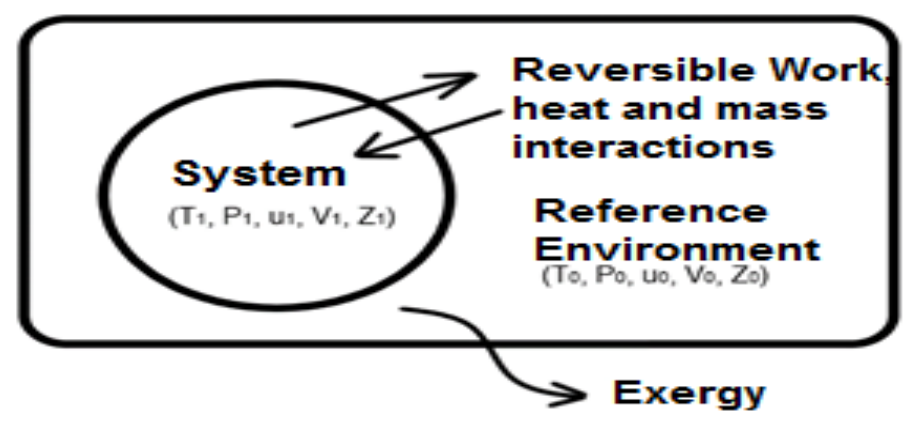

Each system or process that includes exergy streams, requires the balance of the exergy streams with respect to the fuel-product approach as ( Koroglu and Sogut, 2017): 


$$
\dot{E_{F}}=\dot{E_{P}}+\dot{E_{D}}
$$

Where $\dot{E}_{P}$ is the desired exergy change, $\dot{E}_{F}$ is the required input for that desired exergy change and $\dot{E_{D}}$ is the destructed part of the exergy of fuel of any system. In this respect, the exergy efficiency could be given as:

$$
\varepsilon=\frac{\dot{E_{P}}}{\dot{E_{F}}}
$$

In exergoeconomics, every exergy stream, $\dot{E}_{j}$, has its own specific cost, $c_{j}$, and the cost of an exergy stream, $\dot{C}_{J}$, is (Bejan et al., 1996):

$$
\dot{C}_{J}=c_{j} \dot{E}_{j}
$$

As aforementioned, exergoeconomics is based on exergy analysis, thus it inherits the fuel-product approach and costing of the products from economic analysis (Bejan et al., 1996):

$$
\dot{C}_{P, k}=\dot{C}_{F, k}+\dot{Z}_{k}
$$

For a component $k$, sole cost of desired product exergy, $\dot{C}_{P, k}$, is determined with respect to the cost of required exergy and the total cost of investment, operation and maintenance, $\dot{Z}_{k}$. In the form of specific costs, the balance becomes:

$$
c_{P, k} \dot{E}_{P, k}=c_{F, k} \dot{E}_{F, k}+\dot{Z}_{k}
$$

The hidden cost of exergy destruction can be then determined as (Koroglu and Sogut, 2017):

$$
\dot{C}_{D, k}=c_{F, k} \dot{E}_{D, k}
$$

\section{SYSTEM AND ANALYSIS}

The system is an ORC that uses organic fluid R141b as working fluid according to the results that show it is a suitable fluid for the WHR system (Koroglu and Sogut, 2017). As it is shown in Figure 2, the utilizable waste heat from the exhaust gases of the dual-fueled generator engine which belongs to the LNG carrier pass through the evaporator and the economizer of the system to transfer its excess heat to the working fluid R141b. 
Figure 2. General Schematic of the System

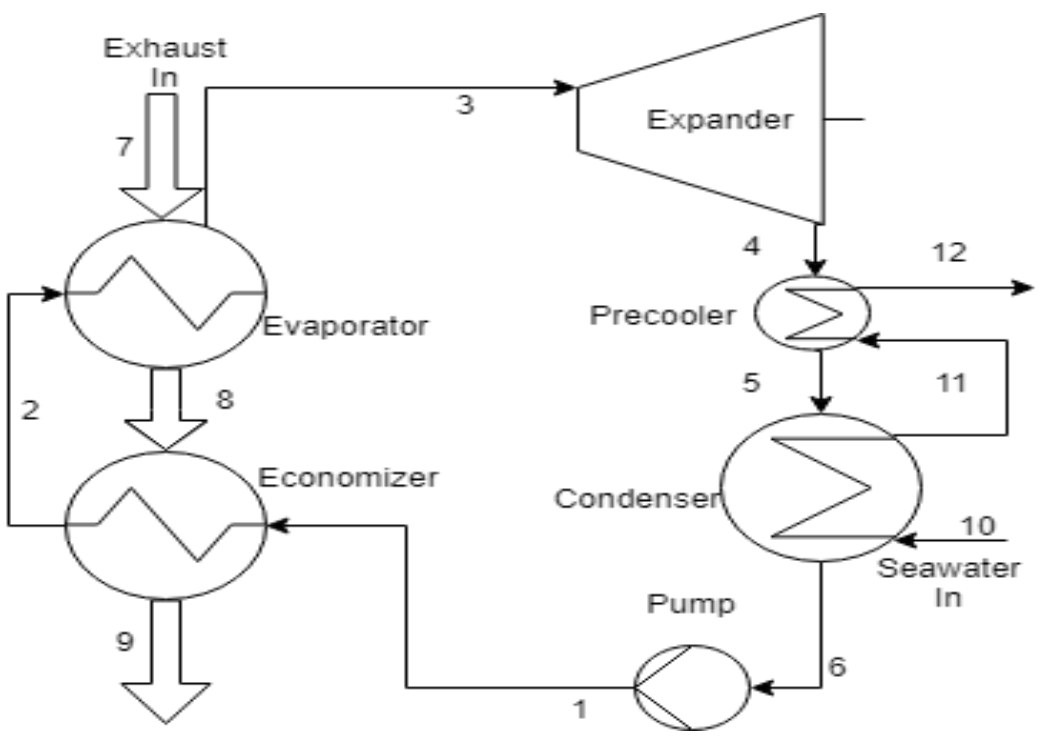

Economizer (ECON) uses the heat to bring the working fluid to a saturated fluid point. Then, the evaporator (EVAP) vaporizes the fluid until the saturated vapor state. The working fluid passes through the expander (EXPN), where its energy transforms into usable power until the condensing pressure. While R141b is in the precooler (PRCL), it releases heat to seawater to cool down from superheated state to saturated vapor state then goes into the condenser (COND) for further condensing with seawater until it reaches the saturated fluid state. The pump gets the fluid and raises its pressure until economizer inlet conditions are achieved, therefore the cycle is completed. The inlet conditions of the exhaust gases are given in Table 1 while thermodynamic data for the system is given in Table 2 .

Table 1: Engine Data used in the Analyses

\begin{tabular}{|c|c|c|c|}
\hline Engine Speed (RPM) & Power $(\mathrm{MW})$ & $\mathrm{T}_{\text {Exh }}\left({ }^{\circ} \mathrm{C}\right)$ & $\dot{m}_{E x h}(\mathrm{~kg} / \mathrm{kWh})$ \\
\hline 514 & 6.8 & 200 & 5.97 \\
\hline
\end{tabular}

It is assumed that the temperature difference between hot and cold fluids in the evaporator and economizer is $15^{\circ} \mathrm{C}$, and the condenser is $10{ }^{\circ} \mathrm{C}$, while pump and expander efficiencies are assumed as $60 \%$ and $80 \%$, respectively. The pressure drops are neglected due to the non-significant effect compared to the temperature difference in the heat exchangers (Koroglu, 2018). Mass flow rate $(\dot{m})$ of the seawater is assumed as $20 \mathrm{~kg} / \mathrm{s}$ with $20^{\circ} \mathrm{C}$ at pressurized 2 bar conditions.

Table 2: Thermodynamic data of the Investigated System

\begin{tabular}{|l|l|l|l|l|l|l|l|}
\hline State & $\dot{m}$ & $\mathrm{~T}$ & $\mathrm{P}$ & State & $\dot{m}$ & $\mathrm{~T}$ & $\mathrm{P}$ \\
\hline 1 & 1.540 & 36.185 & 24.488 & 7 & 11.232 & 200.000 & 1.000 \\
\hline 2 & 1.540 & 168.543 & 24.488 & 8 & 11.232 & 183.543 & 1.000 \\
\hline 3 & 1.540 & 168.543 & 24.488 & 9 & 11.232 & 160.000 & 1.000 \\
\hline 4 & 1.540 & 62.302 & 1.095 & 10 & 20.000 & 20.000 & 2.000 \\
\hline 5 & 1.540 & 34.267 & 1.095 & 11 & 20.000 & 24.267 & 2.000 \\
\hline 6 & 1.540 & 34.267 & 1.095 & 12 & 20.000 & 24.711 & 2.000 \\
\hline
\end{tabular}


The assumptions about the system are like 30 years of lifetime, $6 \%$ of the investment cost is the operation and maintenance costs, yearly working hours are $6720 \mathrm{~h}$ (T. Koroglu and Sogut, 2017), as the beginning of September 2018 the price of the fuel is $450 \$ / t$ ("Current price development oil and gas DNV GL," n.d.), and $15 \%$ of the interest rate. The exhaust gases are assumed that they behave as air at 1 bar pressure. The specific cost of the exhaust stream is calculated by using the fuel price. The dew point limitation is $160{ }^{\circ} \mathrm{C}$, due to corrosion risk (T. Koroglu and Sogut, 2017).

Exergoeconomic analysis requires to develop auxiliary equations as well as exergoeconomic balance equations, due to solving the linear equations derived from the exergoeconomic balances (Bejan et al., 1996; Koroglu and Sogut, 2017). The balance and auxiliary equations related to exergoeconomics as well as exergy balance equations can be seen in Table 3 . The solution of the matrices created by the equations will lead to determining the specific cost of each exergy stream. Afterward, the specific cost of fuel and product exergies for each component could be derived.

Table 3: Exergy, Exergoeconomic Balances and Auxiliary Equations

\begin{tabular}{|l|c|c|}
\hline Component & Exergy Analysis & Exergoeconomic Analysis \\
\hline Pump & $\dot{W}_{P U M P}=\dot{E}_{1}-\dot{E}_{6}+\dot{E}_{D, P U M P}$ & $c_{w} \dot{W}_{P U M P}+\dot{Z}_{\text {PUMP }}=c_{1} \dot{E}_{1}-c_{6} E_{6}$ \\
\hline Economizer & $\dot{E}_{8}-\dot{E}_{9}=\dot{E}_{2}-\dot{E}_{1}+\dot{E}_{D, E C O N}$ & $c_{8} \dot{E}_{8}-c_{9} \dot{E}_{9}+\dot{Z}_{E C O N}=c_{2} \dot{E}_{2}-c_{1} \dot{E}_{1}$ \\
& & $c_{8}=c_{9}$ \\
\hline Evaporator & $\dot{E}_{7}-\dot{E}_{8}=\dot{E}_{3}-\dot{E}_{2}+\dot{E}_{D, E V A P}$ & $c_{7} \dot{E}_{7}-c_{8} \dot{E}_{8}+\dot{Z}_{E V A P}=c_{3} \dot{E}_{3}-c_{2} \dot{E}_{2}$ \\
& & $c_{7}=c_{8}$ \\
& & $c_{7}=0.072 \$ / k W h$ \\
\hline Expander & $\dot{E}_{3}-\dot{E}_{4}=\dot{W}_{E X P N}+\dot{E}_{D, E X P N}$ & $c_{3} \dot{E}_{3}-c_{4} \dot{E}_{4}+\dot{Z}_{E X P N}=c_{w} \dot{W}_{E X P N}$ \\
& & $c_{3}=c_{4}$ \\
\hline Precooler & $\dot{E}_{4}-\dot{E}_{5}=\dot{E}_{12}-\dot{E}_{11}+\dot{E}_{D, P R C L}$ & $c_{4} \dot{E}_{4}-c_{5} \dot{E}_{5}+\dot{Z}_{P R C L}=c_{12} \dot{E}_{12}-c_{11} \dot{E}_{11}$ \\
& & $c_{4}=c_{5}$ \\
\hline Condenser & $\dot{E}_{5}-\dot{E}_{6}=\dot{E}_{11}-\dot{E}_{10}+\dot{E}_{D, C O N D}$ & $c_{5} \dot{E}_{5}-c_{6} \dot{E}_{6}+\dot{Z}_{C O N D}=c_{11} \dot{E}_{11}-c_{10} \dot{E}_{10}$ \\
& & $c_{5}=c_{6}$ \\
& & $c_{10}=0$ \\
\hline
\end{tabular}

\section{RESULTS AND DISCUSSION}

This section presents the results of the exergy analyses first to reveal the exergy destructions of the investigated components and how to regain the exergy. As it can be seen in Table 4. Expander produces $87.14 \mathrm{~kW}$ power while $4.93 \mathrm{~kW}$ part is consumed by the pump to pressurize the working fluid. Hence the net power production of the system is $82.21 \mathrm{~kW}$. The highest exergy of fuel is determined for the expander and it is followed by the evaporator and the economizer. These exergy of fuel results are due to the higher temperature of the required exergy change for the product. 
Table 4: Results of Exergy Analysis

\begin{tabular}{|l|l|l|l|l|}
\hline Component & $\dot{E}_{F}[\mathrm{~kW}]$ & $\dot{E}_{P}[\mathrm{~kW}]$ & $\dot{E}_{D}[\mathrm{~kW}]$ & \multicolumn{1}{c|}{$\varepsilon$} \\
\hline EVAP & 69.890 & 63.628 & 6.262 & 0.910 \\
\hline COND & 15.837 & 2.460 & 13.377 & 0.155 \\
\hline PUMP & 4.931 & 3.058 & 1.872 & 0.620 \\
\hline ECON & 58.942 & 32.666 & 26.277 & 0.554 \\
\hline EXPN & 106.680 & 87.140 & 19.539 & 0.817 \\
\hline PRCL & 3.112 & 1.944 & 1.168 & 0.625 \\
\hline
\end{tabular}

Figure 3 is a representative of exergy destruction ratios of the system components. It is obvious that the economizer has the highest exergy destruction among all with $38 \%$. The component is the reason that the system is in need of extra energy to provide a stable production due to the destructed exergy of $26.3 \mathrm{~kW}$. This is because of the temperature difference, which is due to the inlet temperature of the working fluid is too low compared to the outlet temperature of the exhaust gases. Decreasing this exergy destruction would require decreasing the temperature difference. Moreover, the inlet temperature of the working fluid should be increased with supplying energy from another waste heat source such as jacket water. The second highest exergy destruction occurs in the expander. Exergy amount as $19.5 \mathrm{~kW}$ is destructed in the component that is another burden for the system. This is mainly because of its first law efficiency. If the efficiency is increased with improvements such as decreasing friction, destruction can be lowered. The condenser has $20 \%$ of the overall exergy destruction. Fuel exergy change of the working fluid is relatively high, and seawater has a closer condition to the environment due to the fact that seawater has a high mass flow rate. Thus, the exergy change, which it gains, is low. Decreasing the temperature difference between fluids will decrease the exergy destruction. This will directly affect also the precooler. The smallest exergy destruction occurred in the precooler with $1.7 \%$. The transferred heat for the working fluid to the seawater in the precooler is a small amount compared to that in the condenser; therefore the exergy destruction is low. In the evaporator, R141b and exhaust gas have relatively the highest temperatures, therefore the quality of their energy is also higher. Even the temperature difference is greater than other components, the exergy destruction is lower. Also, it should be noted that the heat capacity of the working fluid plays an important role with a small change of entropy. 


\section{Figure 3: Exergy Destruction Percentages of the Investigated Components}

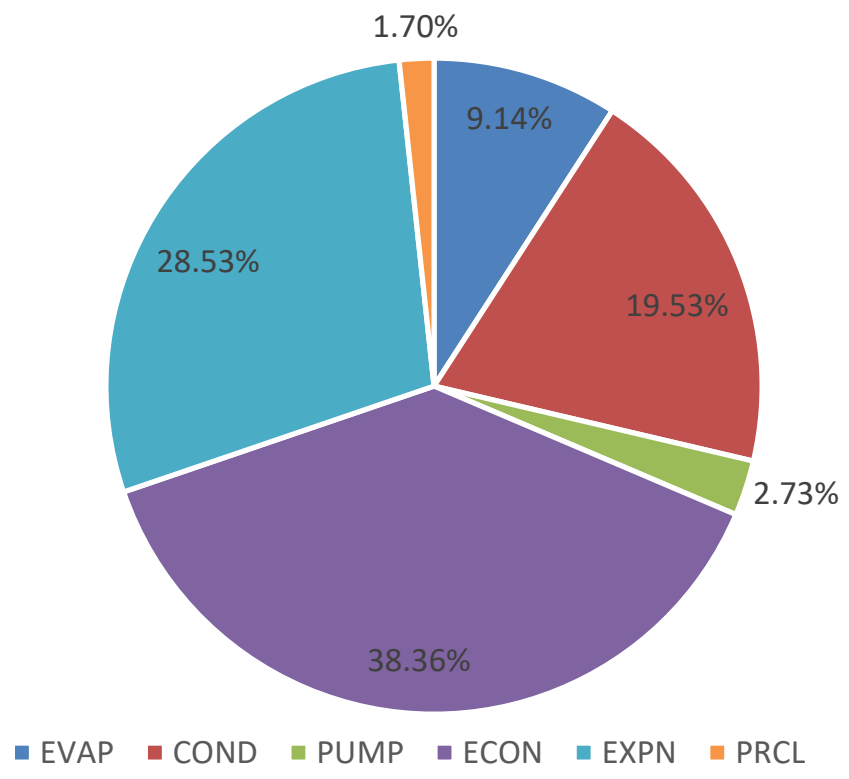

Another result worth mentioning is the efficiency of each component. The lowest exergy efficiency belongs to condenser with $15.5 \%$. Related to this result and its exergy destruction, it could be said that there is huge room for improvement on this component. Besides condenser, all components have a higher efficiency than 55\%. For a small exergy efficiency improvement, it can be said that the expander could recover more exergy destruction. The evaporator is the closest to perfection with its efficiency of $91 \%$. It might be harder to improve further. The exergy efficiency of the pump is relevant to its energy efficiency, which is $62 \%$ and $60 \%$, respectively. Improving this component would lead only small regain of exergy destruction; hence it has small importance as the precooler. The overall exergy efficiency of the system is $67 \%$.

The results of the exergy analysis are not adequate to evaluate the benefit of the components and their improvements alone. The results of the exergoeconomic analysis are given in Table 5, Figures 4 and 5. The price of the energy produced by the system is calculated as $0.2345 \$ / \mathrm{kWh}$. It is determined that the expander is the most expensive component among all with $8.6 \$ / \mathrm{h}$ price and $45.3 \%$ share. The prices of the heat exchangers are similar and around $2.5 \$ / \mathrm{h}$. The pump is the cheapest component in the system. Even it is the cheapest and it has small exergy destruction, calculations show that it loses as much as its component cost due to its exergy destruction. Recovering $6.2 \mathrm{~kW}$ exergy destruction of the evaporator will almost have the same effect as the recovery of the pump's exergy destruction. 
T. Köroğlu Doi: http://dx.doi.org/10.46959/jeess.606042

Table 5. Results of Exergoeconomic Analysis

\begin{tabular}{|l|l|l|l|l|}
\hline Component & $\dot{Z}_{k}[\$ / \mathrm{h}]$ & $c_{F, k}[\$ / \mathrm{kWh}]$ & $\dot{E}_{D}[\mathrm{~kW}]$ & $\dot{C}_{D, k}[\$ / \mathrm{h}]$ \\
\hline EVAP & 2.423 & 0.072 & 6.262 & 0.4509 \\
\hline COND & 2.5663 & 0.1106 & 13.377 & 1.4789 \\
\hline PUMP & 0.5719 & 0.2345 & 1.872 & 0.439 \\
\hline ECON & 2.3543 & 0.072 & 26.277 & 1.8919 \\
\hline EXPN & 8.6371 & 0.1106 & 19.539 & 2.1602 \\
\hline PRCL & 2.5059 & 0.1106 & 1.168 & 0.1291 \\
\hline
\end{tabular}

In total, the burden of the inefficiencies of the components is $6.55 \$ / \mathrm{h}$, while the total cost of the components is $19 \$ / \mathrm{h}$.

Figure 4: Cost Percentages of The Investigated Components

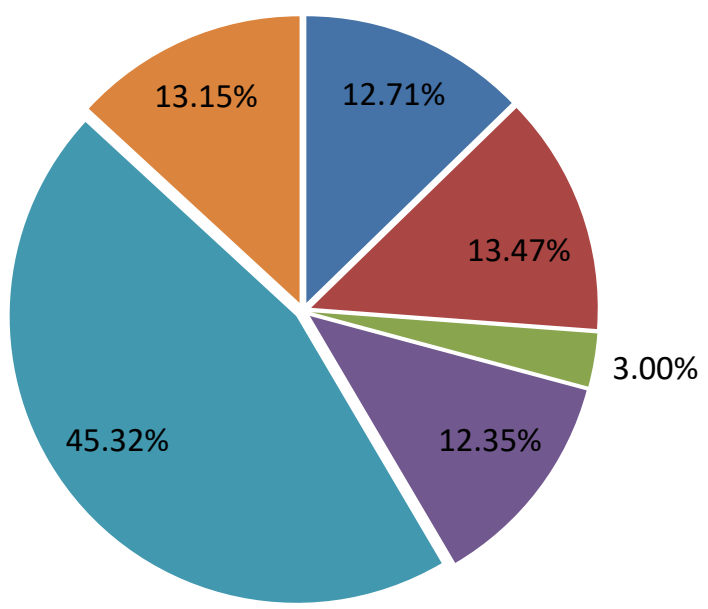

$$
\begin{aligned}
& \square \text { EVAP } \\
& \text { COND } \\
& \text { PUMP } \\
& \text { ECON } \\
& \text { EXPN } \\
& \text { PRCL }
\end{aligned}
$$

On the other hand, the burden of the expander is the highest; even the economizer has the highest exergy destruction. That means, it is more beneficial to improve the expander, which might lead to saving more money than the economizer. Hence, improvement efforts should be focused on that component. Improving the precooler will recover the lowest cost as its exergy destruction. Condenser loses $1.5 \$ / \mathrm{h}$ due to the temperature difference, thus the exergy destruction.

Figure 5: Exergy Destruction Cost Percentages of the Investigated Components

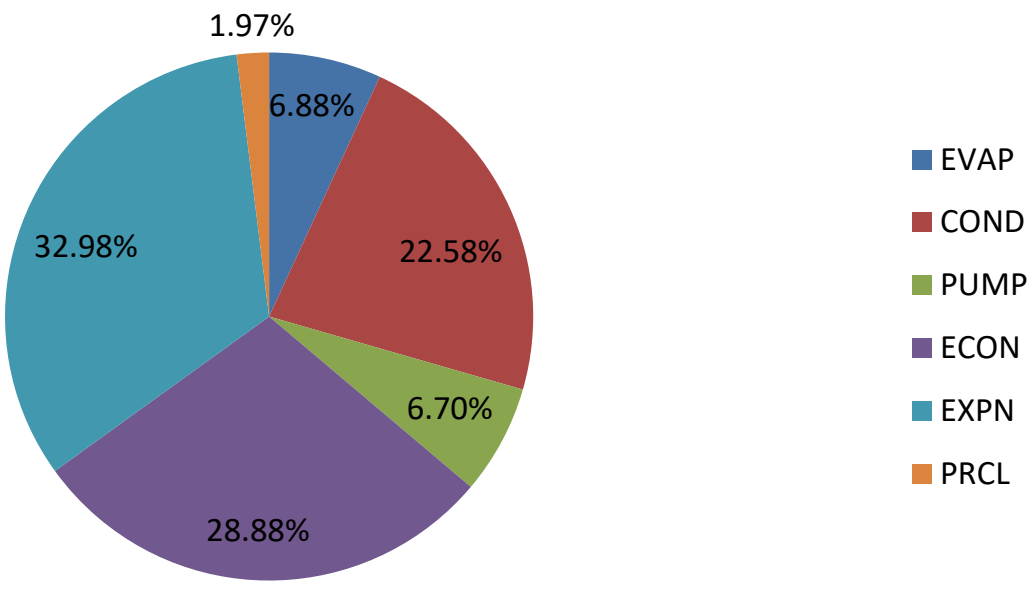




\section{CONCLUSION}

In this paper, an ORC WHR system of an LNG carrier is investigated to present a different perspective for the analysis of an energy conversion system. It has been seen that exergy destruction is the highest for the economizer, and it is followed by expander, condenser, evaporator, pump, and precooler respectively. However, having the highest exergy destruction is not giving an idea of the profit of the system improvement solely. Effect of the component cost, as well as the fuel price, would affect the cost-benefit evaluation. The exergoeconomic analysis reveals that the highest exergy destruction is not always the most important component to improve. More important is to have the information of profit with the improvement, which is provided by the exergoeconomic analysis. It has been presented that the expander has the highest cost of exergy destruction and it is followed by the economizer, condenser, evaporator, pump, and precooler respectively.

The idea behind this study is to give a general conclusion about applicable simple conceptually formed ORC systems with applicable organic fluids in a marine power plant with respect to the exergybased analyses. Moreover, it is aimed to be shown that, exergy-based analyses would give further information about the inefficiencies that occur within the system. Costing the energy with only conventional economics and energy-based analyses would mislead the designer, engineer and investor. Using exergy analysis to reveal the location, magnitude and source of the inefficiencies and costing these inefficiencies could help to recognize the costs and retrieve the economic loss in the direction of more efficient and environmentally friendly systems, lower fuel consumptions and losses.

\section{REFERENCES}

Bejan, A., Moran, M. J. and Tsatsaronis, G. (1996) "Thermal Design and Optimization", Wiley. com.

Cengel, Y. A. and Boles, M. A. (2015) "Thermodynamics : an Engineering Approach", New York: McGraw Hill.

Current price development oil and gas - DNV GL. (n.d.). Retrieved July 17, 2019, from https://www.dnvgl.com/maritime/lng/current-price-development-oil-and-gas.html

Fergani, Z., Touil, D. and Morosuk, T. (2016) "Multi-criteria Exergy Based Optimization of an Organic Rankine Cycle for Waste Heat Recovery in the Cement İndustry", Energy Conversion and Management, 112, 81-90. https://doi.org/https://doi.org/10.1016/j.enconman.2015.12.083

He, S., Chang, H., Zhang, X., Shu, S. and Duan, C. (2015) "Working Fluid Selection for an Organic Rankine Cycle Utilizing High and Low Temperature Energy of an LNG engine", Applied Thermal Engineering, 90, 579-589. https://doi.org/10.1016/J.APPLTHERMALENG.2015.07.039

Kalikatzarakis, M. and Frangopoulos, C. A. (2015) "Multi-Criteria Selection and Thermo-Economic Optimization of Organic Rankine Cycle System for a Marine Application", International Journal of Thermodynamics, 18(2), 133-141. 
Koroglu, T. and Sogut, O. S. (2017) "Advanced Exergoeconomic Analysis of Organic Rankine Cycle

Waste Heat Recovery System of a Marine Power Plant", International Journal of Thermodynamics, 20(3), 140-151. https://doi.org/10.5541/eoguijt.336700

Koroglu, T. (2018) "Developing Criteria for Advanced Exergoeconomic Performance Analysis of the Thermal Systems", Istanbul Technical University, Istanbul, Turkey.

Mahmoudi, A., Fazli, M. and Morad, M. R. (2018) "A Recent Review of Waste Heat Recovery by Organic Rankine Cycle", Applied Thermal Engineering, 143, 660-675. https://doi.org/https://doi.org/10.1016/j.applthermaleng.2018.07.136

MAN Energy Solutions SE (2019) "MAN 51/60DF Project Guide-Marine Four-Stroke Dual Fuel Engine Compliant with IMO Tier III", Retrieved from www.man-es.com.

Mondejar, M. E., Andreasen, J. G., Pierobon, L., Larsen, U., Thern, M. and Haglind, F. (2018) "A Review of the Use of Organic Rankine Cycle Power Systems for Maritime Applications", Renewable and Sustainable Energy Reviews, 91, 126-151. https://doi.org/https://doi.org/10.1016/j.rser.2018.03.074

Quoilin, S., Van Den Broek, M., Declaye, S., Dewallef, P. and Lemort, V. (2013) "Techno Economic Survey of Organic Rankine Cycle (ORC) Systems", Renewable and Sustainable Energy Reviews, $22,168-186$.

Schuster, A., Karellas, S., Kakaras, E. and Spliethoff, H. (2009) "Energetic and Economic Investigation of Organic Rankine Cycle Applications", Applied Thermal Engineering, 29(8), 1809-1817. https://doi.org/https://doi.org/10.1016/j.applthermaleng.2008.08.016

Shi, L., Shu, G., Tian, H. and Deng, S. (2018) "A Review of Modified Organic Rankine Cycles (ORCs) for Internal Combustion Engine Waste Heat Recovery (ICE-WHR)", Renewable and Sustainable Energy Reviews, 92, 95-110. https://doi.org/https://doi.org/10.1016/j.rser.2018.04.023

Shu, G., Liang, Y., Wei, H., Tian, H., Zhao, J. and Liu, L. (2013) "A review of Waste Heat Recovery on Two-Stroke IC Engine aboard Ships", Renewable and Sustainable Energy Reviews, 19, 385401. https://doi.org/http://dx.doi.org/10.1016/j.rser.2012.11.034

Shu, G., Liu, P., Tian, H., Wang, X. and Jing, D. (2017) "Operational Profile based Thermal-Economic Analysis on an Organic Rankine Cycle using for Harvesting Marine Engine's Exhaust Waste Heat", Energy Conversion and Management, 146, 107-123. https://doi.org/https://doi.org/10.1016/j.enconman.2017.04.099

Song, J., Li, Y., Gu, C. and Zhang, L. (2014) "Thermodynamic Analysis and performance Optimization of an ORC (Organic Rankine Cycle) System for Multi-Strand Waste Heat Sources in Petroleum Refining Industry", $\quad$ Energy, $\quad$ 71, 673-680. https://doi.org/https://doi.org/10.1016/j.energy.2014.05.014 
Song, J., Song, Y. and Gu, C. (2015) "Thermodynamic Analysis and performance Optimization of an Organic Rankine Cycle (ORC) Waste Heat Recovery System for Marine Diesel Engines", Energy, 82, 976-985. https://doi.org/http://dx.doi.org/10.1016/j.energy.2015.01.108

Sprouse III, C. and Depcik, C. (2013) "Review of organic Rankine Cycles for Internal Combustion Engine Exhaust Waste Heat Recovery", Applied Thermal Engineering, 51(1-2), 711-722. https://doi.org/http://dx.doi.org/10.1016/j.applthermaleng.2012.10.017

Tsatsaronis, G. (1996) "Exergoeconomics: Is it only a New Name?", Chemical Engineering \& Technology, 19(2), 163-169. https://doi.org/doi:10.1002/ceat.270190210

Wang, X.-Q., Li, X.-P., Li, Y.-R. and Wu, C.-M. (2015) "Payback Period Estimation and Parameter Optimization of subcritical Organic Rankine Cycle System for Waste Heat Recovery", Energy, 88, 734-745. https://doi.org/https://doi.org/10.1016/j.energy.2015.05.095.

Hakem Değerlendirmesi: Dış bağımsız.

Çıkar Çatışması: Yazar çıkar çatışması bildirmemiştir.

Finansal Destek: Yazar bu çalışma için finansal destek almadığını beyan etmiştir.

\section{Teşekkür: -}

Peer-review: Externally peer-reviewed.

Conflict of Interest: The author has no conflict of interest to declare.

Grant Support: The author declared that this study has received no financial support.

Acknowledgement: - 